\title{
Teenagers and New Media: Impact on Foreign Language Proficiency and Cultural Sustainability
}

\author{
By Dr. Boglárka Boldizsár
}

\begin{abstract}
There is a wide range of evidence to support the view that new technologies serve an integral part of teenagers' life. However, in Hungary, it seems that even though the facilities are provided in most of the educational institutions, these are not in regular use due to teachers' lack of competence, the willingness of using them or their constant operational problems.

Using a qualitative, small-scale study conducted in semi-structured focus group interviews $(\mathrm{N}=8)$ with 15 participants in five Hungarian primary schools, the study primarily aims to uncover how teenagers can relate their foreign language advancement to their use of digital devices in their free time. Furthermore, the paper examines their views on foreign language (FL) instruction supported by ICT at school as well as which digital devices and for what purposes they would preferably use them in FL classes. The study implicitly raises the issue of cultural sustainability and tries to find evidence to what extent mass culture affects the Hungarian language proficiency of students.

According to the results, teenagers' attitude towards institutional foreign language learning seems to be quite traditional, as they cannot relate their free time activities spent with digital devices to study purposes at school. Although participants are conscious about the effectiveness of ICT promoting language learning, they think that watching films, instructional videos, or working with projected tasks connected to course books are the major reasons for using digital devices for classroom purposes. Regarding cultural sustainability even within this small-scale study, there is some evidence that English as one of the most influential languages of mass culture can have an impact on the mother tongue language maintenance.
\end{abstract}

Keywords: ICT, digital devices, digital competences, foreign language learning, cultural sustainability

\section{Introduction}

Modern technologies are arguably the indispensable phenomena of the 21 st century, and their significance is greatly increasing, especially nowadays, in the ongoing COVID-19 pandemic, as they have become much more an integral part of our everyday life than they used to be a couple of years ago. Since the appearance and worldwide spread of new technologies, they have caused different kinds of transformation in all spheres of life from the social, political and economic point of view. As having a major influence on education, they provide a great potential not only in formal but also in informal settings for all generations, despite "the ambivalent nature of the effects mass-media has upon the youth" (Treapăt, 2017: 2).

The present study, which was conducted before the first worldwide lockdown resulted from the COVID-19 pandemic, aims to present the theoretical background of the use of ICT in the institutionalized Hungarian education sector and to make a contribution towards the understanding of the practical use of digital devices by teenagers in 
instructional and non-instructional circumstances. Experiencing the growing impact of new media on teenagers' life, interview-based small-scale research was carried out to explore the young generation attitude on ICT use, their digital competence and needs focussing exclusively on foreign language (FL) education. Although the immediate influence of new media on teenagers' life was not intended to be explored by the present study explicitly, some issues are worth to be considered concerning cultural sustainability.

\section{Research background}

\subsection{New media and their influence on teenager's life}

Technological pluralism is an important challenge of the twenty-first century. New media technologies - including the Internet, the "information superhighway" (Ravi, 2012), multimedia, mobile phones, gaming \& animation and many others, - have caused dramatic changes in young people's aim and extent_of media use since the 1990s. Considering the application of digital devices, the repurposing of traditional media can be experienced. This means that individuals can get access to any programs when they feel like with the help of streaming services (Valkenburg \& Piotrowski, 2017). Furthermore, they have also become much more active participants than being just passive recipients (Çöteli, 2019) in their media consumption. This transformation lies in the expanding range and scope of tools used for interactions with media content. As human-computer interaction has also become visually more suggestive of the nature of user interaction with the medium, Internet users are not only allowed "to experience media in newer ways but also actively contribute their own content, given the rise in interfaces and applications that are premised on user-generated content" (Sundar \& Limperos, 2013: 505).

Regarding teenagers' average time spent with media has also shown great changes, meaning "these estimates have now skyrocketed to an average of six (for children) and nine hours a day (for teens)" (Valkenburg \& Piotrowski, 2017: 1), which rate is higher than the time spent at school daily.

If we consider the impact of new media technologies, there are umpteen benefits and drawbacks. Some of the advantages are that they promote global communication processes by breaking down geographic borders and locations, the way individuals interact, travel, entertain themselves or access information. They also offer countless opportunities for educational media for learning and the potential of social media for identity development. However, new media has many potential dangers on teenagers' life by being exposed to electronic crimes (e.g. violence, cyberbullying), pornography and the free global forum of unrestricted information. Furthermore, there are other social and ethical issues that the young generation should be well-informed about and their consequences as well, such as illicit intrusion into electronic systems, copyright infringement, electronic plagiarism and game addiction, not to mention the serious physical impacts of sitting in front of and watching the screens all day (Livingstone, 2012; Ravi, 2012; Valkenburg \& Piotrowski, 2017). These concerns appear on a global level. Parents and educators have a crucial role in dealing with these issues. 


\subsection{The impact of mass culture regarding the young generation and cultural sustainability}

Culture is the entirety of all values of societies, including e.g. moral values, judicial system, etiquette, economic and social structure, language, cuisine, aesthetics (Çöteli, 2019). In regards to culture, new media technologies have generated great transformations in life, having a crucial effect on the whole of current societal dynamics. According to Çöteli (2019), such changes have been implemented in the diversified forms of mass media, technological advancements, social freedom or the new trends of thoughts on human rights and social movement. It is undisputed that culture has become much more instrumentalized and digitalized nowadays, and the main tendencies of the modern world (globalization and mass consumption) influence the lives of all generations. It has to be realised that the young ones are the most vulnerable to these changes especially through the use of new media technologies like the transformed ways of communication and socialization. Moreover, in this accelerated world "mass culture puts the individual into a passive consumer of culture and turns life practices (...) into a consumption activity" (Yavuz, 2009: 144 in Çöteli, 2019: 2).

According to UNESCO's definition, "culture is who we are and what shapes our identity. No development can be sustainable without including culture"1. With the spread of mass culture, a tendency of forming new identities due to the influence of social media can be experienced. Çöteli (2019: 11) has pointed out that ordinary digital identities created by individuals in a virtual world are now reaching a size that can affect culture, leading to serious changes by affecting real life.

Regarding the conceptual framework of cultural sustainability (Soini \& Dessein, 2016) three, partly interlinked representations, have been highlighted. The first representation (culture in sustainability) sees culture as a capital, in other words "as a general process of intellectual, spiritual or aesthetic development, as well as the results of intellectual and artistic work" (ibid. 5). In the second representation (culture for sustainability), culture is interpreted as a way of life, which regulates all of its spheres by reflecting and giving meaning to the environment. The broadest perspective, the third one (culture as sustainability), views the concept of culture as a semiosis and includes the various influences on behaviour and the functions over actions in social life. Regarding the relationship between culture and development, the first representation implies "conservation, maintenance, and preservation of tangible and intangible culture and the diversity of cultural expressions" (ibid. 5). The second perspective translates culture to the local conditions and highlights it as "a resource for development and a means to conceptualize, regulate, and shape development processes". The third representation refers to a fundamental paradigm shift, in which development is considered as a cultural process, in which sustainability becomes an integral part of a culturally-embedded development.

Examining cultural sustainability in terms of the global spread of mass culture, all three representations have to be taken into consideration. The role of education is crucial in this respect, as it should "empower learners to make informed decisions and responsible actions for environmental integrity, economic viability and a just society, for present and

\footnotetext{
${ }^{1}$ https://en.unesco.org/themes/culture-sustainable-development
} 
future generations, while respecting cultural diversity" (UNESCO on Education for Sustainable Development ${ }^{2}$ ). Therefore, one of the main responsibilities of education in connection with reducing the negative impacts of mass culture dominance is perhaps teenagers' identity formation including the maintenance and preservation of their own culture and the awareness-raising for the environment.

\subsection{New media in education}

\subsubsection{Structuring digital competence}

New technologies play a crucial role in teenagers' daily activities as well, who can do multi-tasking by navigating and manoeuvring on various digital platforms (Livingstone, 2003), and are competent users of smartphones and computers (Gfk Hungária, 2010; Mátyásné Nagy, 2015; M. Fazekas \& Cs. Czahesz, 2011, etc.). However, the rate of exposition to these devices and the level of ICT competence can vary strongly even among the young generation. According to Buda (2013), Prensky's (2001) previously used homogeneous categories (digital natives and digital immigrants) seem to be much more polarized today. Therefore, the classification related to 'digital native' solely based on age group can be misleading. Taking into account quality indicators for the use of digital technologies in group formation will be more in line with the real situation. Buda identifies five subgroups based on proficiency levels: digital hermits, explorers, nomads, migrants, settlers and conquerors. He concludes that nowadays there has been an even wider gap between some of these groups, but in the case of others the difference has recently narrowed (e.g. between digital migrants and settlers). All in all, the picture has become much more nuanced within the whole society.

\subsubsection{The use of new technologies in the Hungarian educational and non- educational context}

Regarding the impact of new technologies on the educational setting in Hungary, the following themes have been researched on regional and national levels: learners' ICT competence, the purpose and frequency of using digital devices (e.g. IT'TK, 2007; R. Tóth and Molnár, 2009; Sikné Lányi, 2000; Sós, 2005; Török, 2001), their attitude towards ICT, IT culture and lifestyle, and computer science studies (Hanczár, 2006; Dancsó, 2008; etc.). However, there have been few investigations on ICT in Hungarian FLT (foreign language teaching) (e.g. Boldizsár, 2018; Czékmán et al., 2017; Kétyi, 2016, 2017). Therefore, this study aims to find out more about teenagers' view of new media and how this can promote their FL proficiency.

ICT in Hungarian primary education is taught as a separate subject and digital devices are tools for specific tasks in other subjects, e.g. in language learning, mathematics, natural sciences and arts. Considering the infrastructure of primary and secondary education, according to the latest research results the computer rooms of schools are well-equipped with ICT (Molnár \& Pásztor-Kovács, 2015), but the rate of technological equipment of the general or subject-specific classrooms usually lag in this respect and big differences exist on the institutional level (MOD 2016). Moreover, even if the facilities are provided in the educational institutions, some devices are inadequate as they are outdated and

\footnotetext{
2 https://en.unesco.org/themes/education-sustainable-development/what-is-esd
} 
therefore need constant repair, or some classrooms lack the necessary equipment (see also Boldizsár, 2017). Furthermore, it can also be the case that digital devices are not in regular use due to several reasons, e.g. teachers' lack of competence or confidence, delusion, fear or unwillingness to use them; as well as the constant operational problems (Ollé in B. Tier, 2012; MOD, 2016).

Buda (2013) approaches the issue of ICT from the teacher side and lists some of their basic fears. Firstly, he mentions the frustration when being exposed to technical problems, which make them feel vulnerable to machines (e.g. the problem assembling their devices, the necessary recalibration of interactive boards, or the pen drive that the computer does not recognize). Secondly, teachers often experience insecurity as they think their subject knowledge is less and less worth or up-to-date. On the one hand, sometimes students ask questions that they cannot answer as they have not come across the particular website which deals with the problem in question. On the other hand, they also noted that students ask less and fewer questions as they turn to the Internet for proper answers instead of the teachers, although students are warned of the dangers of the websites as some of them provide false information. Thirdly, teachers have doubts about what skills need to be developed at school, about the future needs of the next generation, which is difficult to predict at the moment (Szebeni, 2010). In addition to this, students often feel what they learn at school is completely useless for them, so "what they are learning in school has little or nothing of value to contribute to who they are once the bell rings" (Jenkins, 2009). Fourthly, as current norms are in constant change due to the accelerated life through the ICT, the pedagogues have the pressure of the society of being the role models. Besides, they also have to adapt to the conditions and regulations of the educational institution management. Unfortunately, this internal distress can affect teachers' work in the short term, but in the long run, it will inevitably have a personality and health-destroying effect. Apart from the institutional facilities and the proportion of the use of ICT in education, it is worth to note what for and how frequently teenagers use digital devices in a noninstructional context. According to M. Fazekas \& Cs. Czahesz (2011) Hungarian teenagers (aged 14-19) spend 1-2 hours with computers during the weekdays but this rate of exposure at the weekends is usually much higher (2-3 or more than 4 hours). Students use the computer or their smartphones mostly for entertainment or relaxation $(67,8 \%)$, as well as for communication $(66,7 \%)$, which also has a significant role in their life, especially in socializing and networking. Considering the rate of computer or Internet use in institutional circumstances the same figures are shown $(69,5 \%)$, but these are not to be related to the use of ICT in the formal setting. Furthermore, it seems the development of digital literacy is not yet a prominent part of the knowledge transferred by the school, and teachers make little effort to use modern technologies or the existing tools are not always effectively utilized (MOD, 2016).

To solve the above-mentioned problems, more and more up-to-date and appropriate teacher training programmes are needed to provide educators with the necessary skills and methodological considerations to cater for the needs of the digital native generation (Kárpáti, 2003; Főző, 2006; Boldizsár, 2017; 2018). Mátyásné Nagy (2015) also points out the necessity for the development of a high-level digital curriculum. Fortunately, nowadays a high number of relevant teacher training programs and useful publications available, which serve as general guidelines on how to incorporate new technologies into the 
teaching-learning process effectively (Turcsányi-Szabó \& Abonyi-Tóth, 2015). Moreover, to bridge the gap in the improper infrastructure of some schools (e.g. as a result of the lack of proper technological equipment) the idea of BYOD (Attewell, 2007) is introduced meaning that students and teachers bring their mobile devices (laptops, netbooks, tablets, smartphones, etc.) into school and use them to access institutional information, applications and services supporting learning. This idea was first introduced by the recommendations of the Hungarian Digital Education Strategy in the context of establishing the Sample Digital School Project (IVSZ, 2017).

In summary, there is still room for improvement in Hungarian ICT education, but there are more and more examples of good practices, which is promising.

\subsubsection{New technologies in the service of FLT and teachers' changing roles}

According to Molnár (2011:1042), a great difference exists between students of the 20th and 21 st centuries, "which not only creates new demands on education, but these needs can no longer be met by traditional methods". Therefore, she thinks that the success of education lies in its ability to make an attitude change towards ICT and to adapt rapidly to the endless changes of the digital world to be able to keep up with the demands of the modern age, the world of work.

Since the 1990s the use of networks and the Internet became more and more widespread in education and also in the methodology of foreign language teaching. Language teachers reacted fast to the new technological challenges and started to incorporate these into their teaching practice. Web 2.0, the IWBs and the social networks meant a breakthrough in language teaching as they offered a much wider variety of possibilities (Dudeney \& Hockly, 2012). Cetto (2010) mentions three major platforms that can provide tools for enhancing language teaching and learning: the web, the network-based communication through email, chat programs, wikis, blogs, etc. and the CD-ROM or the hypermedia applications. She points out that CD-ROMs are still popular tools as they support textbooks with supplementary material. However, the web and the network-based communication applications can provide a wide display of context for interaction, and the World Wide Web also offers an "endless source of materials for content-based lessons and provides plentiful opportunities for interaction with cultural authentic material” (ibid. 120).

New technologies have a long list of advantages in FLT such as promoting interactivity, providing immediate feedback, creating the chance for collaborative or competitive learning as well as for personalized learning experience and differentiation. Furthermore, regarding the time factor, synchronous and asynchronous learning opportunities are reinforced by the online and downloaded resources for learning, which involves real-life, interesting and motivating tasks (Főző, 2006; Szabó, 2012). However, according to Blake (2008), there are some common misconceptions in regards to ICT in language teaching that have to be considered. Firstly, it is highlighted that "there is not one technology best suited for language study" (Blake, 2008:9). Furthermore, we need to take into account that technology is "theoretically and methodologically neutral" (ibid. 11), so it is important to understand how it is utilized as a pedagogical tool or a cultural practice. Moreover, as new devices are being created day by day, it is not true that "today's technology is all we need to know" (ibid. 13), as no educational institution can prepare teachers for these changes. Lastly, he highlights that even if technological tools can effectively foster the teaching- 
learning process they "will not replace teachers in the future" (ibid. 14). Hoopingarner (2009) adds that it seems that with the help of technology, which is a tool that can enhance the teaching-learning process by providing a platform for interaction and task-based learning, the quality of the learning experience can be raised, but a computer cannot substitute a teacher and cannot transform someone into a good teacher.

Among the expectations towards pedagogues in general and also foreign language teachers the digital skills they possess are very important in the development of students' learning processes, as they are supposed to introduce technologies as tools in the service of education (Fernández-Cruz \& Fernández-Díaz, 2016). In an ideal situation after graduation teachers should not only have a solid understanding of how to use new technologies to support learning. They should possess up-to-date methodological knowledge and practical experiences of the effective use of digital devices in order to be able to reflect on "how to best integrate technology within their methodologies to enhance the effectiveness of their teaching and learning in their classrooms" (Cetto, 2010:119). However, Polónyi (2017) argues that it is unrealistic to expect teachers to keep up with the rapid development of new technologies, as the teacher training institutions cannot provide them with an up-to-date curriculum of how to incorporate digital devices into their methodology to cater for the needs of the young generation. Cetto (2010) states that what teachers can do is that focus on the instructional goals and objectives, their teaching styles which can be matched to the available technological platforms that the educational institution can provide for them. Moreover, there is a wide range of teacher training programmes that are available provided by the state or by private corporations. But it is still a long-term process.

\section{Research design}

\subsection{Research setting and participants}

This qualitative small-scale study ${ }^{3}$, which was conducted in the form of semistructured focus group interviews, is the continuum of previous research carried out by multi-criteria online questionnaires (Boldizsár, 2018) among 660 participants $\left(5^{\text {th }}-13^{\text {th }}\right.$ formers) from 41 upper-primary and secondary educational institutions of Győr (a major city in the North-West of Hungary). This previous study aimed to explore students' ICT competence, their use of new technologies in their free time and the impact of multilingual websites or applications on their foreign language advancement. Further investigations focussed on students' attitude on what digital devices and for what purposes they would incorporate them into the foreign language lessons to make that more effective.

As for the present qualitative research, which aims to explore the major aspects of the previously mentioned issues in more detail, students were selected by non-probabilistic sampling technique (c.f. Palys \& Atchison, 2014) from five primary schools, which were previously involved in the online study. Before the interview, participants were informed about the research purpose, data collection procedures, and what would happen to any data obtained.

\footnotetext{
${ }^{3}$ The research reported in the study was carried out with the support of the project called "Internationalisation, initiatives to establish a new source of researchers and graduates, and development of knowledge and technology transfer as instruments of intelligent specialisations at Széchenyi István University, Hungary”, EFOP-3.6.1-16-2016-00017.
} 
Although the two studies used similar or in most of the cases the same research questions, the major differences between them are the range of sampling (participants are chosen only from upper-primary schools) and the more in-depth analysis of certain research questions.

\subsection{Research aim, data collection and analysis}

The study aims to explore how teenagers in the upper primary school (ages 1115) can relate their foreign language advancement to their use of digital devices in their free time. Furthermore, the paper examines their views on FL instruction supported by ICT at school as well as which digital devices and for what purposes they would preferably use them in FL lessons to enhance their language proficiency.

Eight semi-structured focus group interviews were conducted and recorded in Hungarian (see Fig. 1). Fifteen participants (5 males and 10 females) took part in the research, whose first foreign language at school is English and/or German. The interviews unfolded in similar ways, guided by core questions to elicit information linked to the research aims. Audio recorded interview data were transcribed verbatim.

\begin{tabular}{|c|c|c|c|}
\hline $\begin{array}{l}\text { grades } \\
\text { (ages) }\end{array}$ & $\begin{array}{l}\text { first foreign language } \\
\text { - level of language proficiency (CEFR) }\end{array}$ & $\begin{array}{l}\text { number of } \\
\text { interviewees }\end{array}$ & $\begin{array}{l}\text { number of } \\
\text { interviews }\end{array}$ \\
\hline $\begin{array}{l}\mathbf{5} \\
(11-12 \text { yrs.) }\end{array}$ & English - A1/A2 (3 students) & 3 & 1 \\
\hline $\begin{array}{l}6 \\
(12-13 \text { yrs. })\end{array}$ & $\begin{array}{l}\text { German - A2 (2 students) } \\
\text { English - B1 (3 students) }\end{array}$ & 5 & 3 \\
\hline $\begin{array}{l}7 \\
(13-14 \text { yrs.) }\end{array}$ & $\begin{array}{l}\text { English and German - A2/B1 (1 student) } \\
\text { English - A2 (2 students) }\end{array}$ & 3 & 2 \\
\hline $\begin{array}{l}8 \\
(14-15 \text { yrs. })\end{array}$ & English - B2 (4 students) & 4 & 2 \\
\hline & total: & 15 students & $\mathbf{N}=8$ \\
\hline
\end{tabular}

Fig. 1. Research participants' quantitative data in the focus-group interviews

Interview questions were constructed around three major themes within the field of new media and foreign language studies. The first block of questions focussed on the accessibility of digital devices, the average time spent with them in their free time and students' views on their ICT competence. Secondly, teenagers were asked what type of activities they prefer to do with the available devices and which languages are mainly used when browsing the Internet, being online and engaged with different applications or playing games. If participants showed interest in foreign language content in any respect, they were also asked to express their opinion on whether this had any influence on their FL skills and content knowledge development. Finally, institutional language teaching was studied based on what kinds of ICT tools are generally used in class and for what purposes. Connected to this, student opinion was investigated on which digital devices and for what activities they would find worth to be incorporated into the foreign language classes to better meet their needs (see Table 1. in Appendix). 
Before the interview research, a larger-scale data collection was conducted in the form of online questionnaires ${ }^{4}$, which combined open-ended questions with forced-choice answers. In this study, the data of children between the age of 11 and 15 are used with the purpose of triangulation (see Patton, 1999).

\section{Research results}

Concerning research results, the quantitative figures of the multi-criteria online questionnaire are compared with the qualitative data of the interview findings. First, some general information about the participants' foreign language studies is presented then the results are introduced concerning the three major themes of the interviews.

From the online questionnaires (Boldizsár, 2018) it has been noted that despite the city's closeness to the Austrian border where the research was carried out, students' choice of the first foreign language learnt in the primary school is rather English-focussed (c.f. English: $68,1 \%$, German 30,9\% of respondents). This phenomenon was also highlighted by another non-representative national research (Kuti \& Öveges, 2016), as well as one which pointed out that the German language, "which had until recently enjoyed a strong regional significance, has lost a considerable amount of importance" in this region (Rieger, 2009:97). This tendency can also be seen in the convenience sampling of the interviewees (see Fig. 1).

\subsection{Access to and time spent with digital devices and ICT competence}

The first part of the interview aimed to explore student access to digital devices at home, the time spent with the new technological tools and their opinion about their digital competence.

Finding 1: Interviewees, who mostly regarded themselves as competent users of new media, have access to a variety of digital devices at home and use them every day with huge individual differences in respect of time.

Regarding student access to new media, the findings showed that most of the interviewees have a wide range of digital devices at home. The rate of owning a smartphone is of the highest percentage of all the available devices, meaning that each respondent has one in their possession. Moreover, most of their households contain a tablet $(73,3 \%)$, a PC $(66,6 \%)$ and/or a laptop $(53,3 \%)$ and of course a TV (73,3\%). Also, a high number of students reported having access to an Xbox or a Play Station $(60 \%)$ used mostly at the weekends. However, only a few of them had a digital camera or a video recorder, and a Google Home Mini device is owned by one individual. It was also interesting to note that neither an mp3, a CD/ DVD-player, nor an e-book reader has been mentioned by any of the participants in the interviews although these technological tools were represented at a relatively high proportion (34-50\%) in the online questionnaire study among teenagers at the same age range.

Concerning the length of exposure to digital devices mentioned by the interviewees, it was found that all of them use their smartphone, tablet or laptop daily, but there are huge

4 The online questionnaire was filled in by 660 students $(N=394$ aged between 11 and 14/15 from primary schools, $\mathrm{N}=266$ aged between 15 and 18/19 from secondary schools) 
individual differences related to the length of time devoted to them. This means that research participants are exposed to digital devices between half an hour to even eight hours a day (c.f. Valkenburg \& Piotrowski, 2017). Moreover, weekend exposures are usually higher than on weekdays. By comparing the interviewees' average time spent with digital devices a day to the data gained by the online questionnaire the same tendency can be seen. This means that a high number of teenagers (about $40 \%$ ) use new technology an hour or two, and much less (approximately 20\%) 3 to 4 hours a day. Both the questionnaire and the interview results show that there are a few students who seem to be online all day, spending more than six hours with their digital tools, which represents about $6 \%$ of the cases. Moreover, it was also found that the time spent with new technologies does not seem to be related to a particular age factor but it is more likely to be connected to what they use them for.

In the case of proficiency, interviewees said to be competent users, especially with their own devices. This was specified in multiple ways by them, usually very subjectively. Two interviewees rated themselves as 9 and 8,5 on a ten-point scale, which seems to be quite high in respect of proficiency, and two of them compare themselves to their parents' or peers' competence:

Generally, I can figure it out myself in such situations, better than my parents, [...] but as I realised I am a bit behind my classmates in this field. (S11, age 15)

\section{I think compared to my age I am better than other children. (S13, age 13)}

A few of them $(\mathrm{N}=2)$ specified their ICT competence related to different devices saying that they were much better at using the smartphone and the tablet than the computer. However, the rest of the respondents stated that they were able to use new technology with high confidence, so they were well versed in using digital devices.

To specify what they mean by digital competence, it was found that downloading and uploading information, sending messages and operating basic software applications are routine tasks for all the participants although two 11-year-olds and one 13-year-old sometimes ask for help from their elder siblings if they are stuck. However, none of the respondents felt confident in programming.

Considering the results of the questionnaire, the same tendency is shown as in the interviews that is that the majority (91\%) of the participants considered themselves as competent ICT users and only 3,5\% stated that they were incompetent in this respect.

\subsection{Purpose of using digital devices and their influence on student FL proficiency}

The study also aimed to explore what purposes participants use new technologies for, what websites or language content they are usually engaged with (foreign language or native language ones), and whether they could benefit from using the digital devices in regards to their FL advancement.

Finding 2: It is found that the three most popular pastimes mentioned by the interviewees are watching YouTube videos, films, and listening to music; visiting social media sites; using different applications on phone especially for study purposes and also for having fun (e.g. playing games). Furthermore, the language content, which they are 
most engaged with, are both Hungarian and English, and in the opinion of the majority of teenagers being interviewed foreign language contents or sites have positively influenced the development of their oral skills (speaking and listening) and vocabulary expansion in the foreign language. In the following, the results will be analysed in more detail.

Firstly, regarding videos and music, teenagers select them on their major interests or hobbies. In the interviews the following types have been mentioned: experimental videos, 5-Minute Craft, beauty videos, engineering or biking videos, influencers' playing computer games and talent shows. Every participant (except for one) likes visiting foreign websites or watching films in a foreign language or the dubbed version with foreign subtitles. Those who have a higher level of English often ignore the subtitles and enjoy the natural flow of the foreign language.

I used to watch films with subtitles, but now I can skip the subtitle, so I can watch and understand [films] without that. (S12, age 15)

Films or series are not only watched on the computer or smartphone but also TV (mentioned by $40 \%$ of respondents). Finally, playing on a game console especially in a multiplayer mode is popular among males (ages 14 and 15), although female participants also reported that they have access to Xbox, but they did not mention whether they spent time with that.

Secondly, the social media sites (Facebook, Instagram, the younger ones mentioned Messenger, Viber, Snapchat or Amino) do not seem to be so influential in the case of time spent with digital devices compared to watching videos. Most of the interviewees highlighted that they use them to keep in touch, chat with each other or exchange information about homework.

The third most influential activity among the interviewees is the use of special smartphone applications such as Google Translator, online dictionaries, Duolingo, especially with the purpose of language learning. Wattpad is also used by 2 students. One of them is just about to finish her first novel in Hungarian but has started writing on the same platform in English as well. Finally, other applications like different photo and video editors, are also used by 3 female interviewees regularly. Furthermore, in regards to computer games, one-third $(27 \%)$ of the teenagers play them regularly, generally the younger ones (11-12-year olds). Some (20\%) older students (13-14-year-olds) used to play Minecraft when they were younger. However, Xbox games are still very popular mostly among the 14-15-year old males, who mentioned that their English had been improved by playing as a result of playing with friends at the weekends:

I have always been playing [Xbox] in English, and it helped me a lot, [...] and as I watch the short videos in between the games that are real US English [...] and it inspires me a lot ... (S12, age 15)

... as it [the Xbox GTA5 game] is not translated into Hungarian so we needed to adapt [to this condition] (S10, age 15)

To sum it up, although other activities were also mentioned, such as browsing the net for information needed for homework or using the Word or PowerPoint for study purposes, 
the most widely used activities with digital devices showed nearly the same tendency in the online questionnaires as well (69,3\% - YouTube videos; 64,5\% - chat apps; 61,7\% - music; $47,8 \%$ - social media sites; $42 \%$-films; $31,9 \%$ - info search; $29,9 \%$ - games), except for the use of the Internet for searching relevant information for their studies $(31,9 \%)$ which was a bit higher rate compared to the interview results.

Considering the proportion of the native and foreign language content or sites used with the help of digital devices, interviewees mentioned Hungarian (86,7\%) and English (80\%) in most of the cases. Even the students, whose first foreign language was German at school, prefer to browse the Internet in English. Some of the 15-year-old interviewees $(13,3 \%)$ do not visit Hungarian sites at all, just English ones as they find those sites more up-to-date or informative than the native ones (especially in the case of the latest news and technological innovations). This can sometimes create a special situation where they learn special terminologies in the foreign language while they are still not familiar with their native equivalents.

My other hobby is mountain biking, and I usually watch videos in connection with them, and it often happens that when I am talking about bikes with my friends, and I tell them an English word instead Iof a Hungarian one], 'cause I know the special term of an [hesitation] I don't know for example a piece part or anything only in English, and it happens regularly, and I cannot say it in Hungarian, because I don't know it just in English. (S12, age15)

Furthermore, regarding language proficiency gained through dealing with foreign language content in non-institutional circumstances, most interviewees think that these activities have promoted their FL advancement and felt a positive change. Some of them have pointed out the motivating force of the Internet. A female participant mentioned that browsing the foreign language sites was an eye-opener for her which made her realize the importance of language learning. She has also become aware that the Internet provides further potential for everyone to pick up a new foreign language next to those being learned at school.

I think my English has improved a lot over the past few years, and the Internet has made me realise that I want to learn other languages as well. Now, for example, I would like to learn Chinese and sometimes I do that, and I would also like to start Korean". (S7, age 13)

All in all, the greatest benefits pointed out by the interviewees is vocabulary expansion $(73,3 \%)$ and oral skills development, more precisely listening comprehension (40\%) and communication skills development (33,3\%). A few participants (13-13\%) highlighted the development in the following areas as well: pronunciation, reading skills, text comprehension and grammar. Comparing the results with the online questionnaire data, the advancement in oral skills (speaking, listening) and language content (pronunciation, vocabulary) are mentioned in the first place. However, development in reading skills and the complex skill of translation (oral and written) is reported by a high rate of students $(58,9-69,5 \%)$. Finally, in the interviews, translation is not being referred to as a skill, but an activity, e.g. using the Google Translator or solving a school task and the homework. 


\subsubsection{Institutional language learning - ICT tools used in class, students' needs}

The third part of the interview focuses on the use of new technologies in the FL teaching-learning process. Student opinion about the importance of incorporating digital devices into the FL lessons is investigated and also their needs towards the support of new media to foster their foreign language proficiency.

Finding 3: Using varied digital devices during FL lessons (e.g. smartboards, smartphones, PCs and projectors) is just rarely experienced by the majority of the interviewees. It seems that $\mathrm{CD}$ and $\mathrm{mp} 3$ players are still the most popular technological tools in upper primary education, which are incorporated in the language learning process relatively frequently, and mainly used for skills development. Student opinion on the use of new technologies in FL lessons mostly reflects a rather traditional point of view, but some of the teenagers have expressed their wish to do such activities in the lesson which they are usually engaged within their free time (e.g. watching and editing videos or creating films; setting up a chat group; using language learning apps). They think that smartboards, laptops, tablets and smartphones could be used for these purposes.

Concerning the type of digital devices being used in FL lessons in more detail, the CD player is the most often used technological tool (mentioned by $73,3 \%$ of participants). According to the interview results, it is for listening skills development and testing, or simply enjoying the melody of songs to have fun. Furthermore, mp3 players on laptops are also reported to be in use (by $20 \%$ of students). In the case of the other devices, only two interviewees $(13,3 \%)$ have experienced the frequent use of the projector and smartboard/ computer combination for watching PPTs about different topics or cultural themes. Many of the participants $(40 \%)$ have stated that the smartboard is not used at all, because of either not being available in the classroom or the teacher ignores them and rather sticks to the traditional teaching tools, such as books and workbooks. Two classmates have mentioned that even if there is a smartboard in a classroom, the teacher uses it only for projecting the exercises of the students' book and workbook:

... and sometimes if we are in a room with a smartboard (S14, age 13), but then she [the teacher] only projects the workbook or the students' book to enlarge them (S15, age 13), [...] and we have watched a video once (S14 and 15), [...] and listened to music at Christmas ... [with] a CD player. (S15)

However, there are some cases when digital devices (probably the smartboard, but it is not stated clearly by the students) are aimed at non-traditional purposes such as watching videos on YouTube (in interview 5). In another interview, it is mentioned that sometimes the smartphones can be used in language lessons:

- Um... for example when practising for the competency test ${ }^{5}$, and she [the teacher] always has the listening test on [her] computer, and we always complete the tasks with the help of our phone. (S2, age 12)

- Yes, we can sometimes have our phones to browse different sites (S3 age 12), because she [the teacher] sends us the file. (S2)

- In email? (Interviewer)

${ }^{5}$ Assessing global competence in PISA 


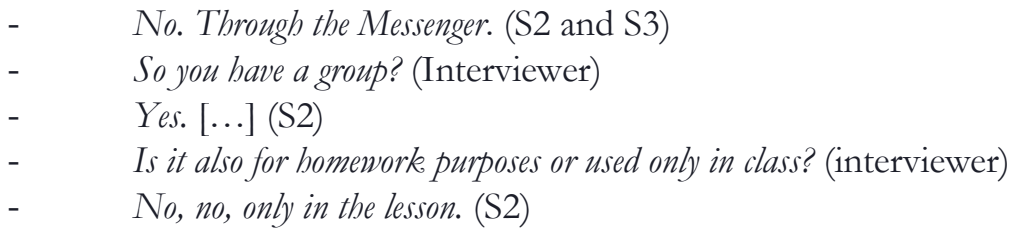

Comparing the results with the online questionnaire data on the types of digital devices used in the language lessons it is shown that DVD and video players cannot be found in schools $(57,6 \%)$ or are not used at all $(12,2 \%)$. Regarding CD players, a very diverse picture is presented. On the one hand, nearly half of the participants $(41,8 \%)$ reported the lack of devices, on the other hand, in other cases, these are in regular use $(25,3 \%)$ or very rarely used $(14,9 \%)$ during the FL lessons. The computer-projector combination is more often employed $(68,8 \%)$ than the previous devices, although their frequent use is mentioned by a much less number of students $(39,6 \%)$. Furthermore, according to $72,3 \%$ of the teenagers if smart boards are available these are used by the language teachers although with varied frequency (rarely: 31,7\%, often: 40,6\%).

All in all, in some cases the interview and the questionnaire results show differences, e.g. in the rate of availability and the real use of smartboards, computers, projectors, and CD players. Therefore, further investigations are needed in this respect.

Regarding interviewees' opinion on which digital devices they would find beneficial to incorporate into the teaching-learning process, they have mentioned smartphones, tablets, laptops, projectors, and smartboards. The most often specified digital tools are smart boards and tablets, but in many cases, the use of a particular device is only implied through the activities highlighted by the students.

Concerning the purpose of using new technologies, teenagers have brainstormed many useful ideas. Their recommendations could be clearly distinguished on the basis of traditional or non-traditional language teaching tasks and activities. According to this distinction of the classroom activities carried out with digital devices, teenagers' views on what to incorporate into the language lessons fall into the traditional type of language teaching in most of the cases, as these tasks aim to develop language skills or content areas in a direct way (especially productive and receptive oral skills, translation, vocabulary, and pronunciation). However, some participants, especially the older ones (14-15-year olds) have called for the need of those types of activities that they would otherwise do in their free time, such as watching films, series or making private videos; using special applications, and communicating through chat programs. The three types of activities mentioned are also suitable for skills development indirectly.

Firstly, regarding films and videos two-third of the interviewees $(66,7 \%)$ wish to watch films, series or (educational) videos in the English lesson. Apart from having fun, they think that it can enhance their oral skills (listening and speaking) and they can also have better speech comprehension. Besides watching videos, making short films in groups and presenting them in class is also listed by $20 \%$ of the interviewees. It is a creative and highly motivating task for teenagers as they are inspired by searching for pictures and photos to the videos on the Internet and use photo and video editor software programmes or applications. Therefore, it not only promotes FL but also IT skills. 
I think it would be very good if we could write a text and have it checked by the teacher and then we could record it on video and maybe look for pictures in English on the Internet or video. (S7, age 13)

Secondly, some teenagers $(26,7 \%)$ think that special language learning applications (Kahoot, Duolingo) could also be used on smartphones or tablets in FL lessons as well giving the chance of both competition and individual progress. Furthermore, online and offline dictionary applications or Google Translate is a helping hand in the lesson which could make e.g. text comprehension faster and more effective. One of the interviewees has pointed out that using Google Translate can even be a source of fun. In other words, it can develop metacognition as is beneficial for comparing the structure of the foreign language with that of the native language. It can also draw attention to any ambiguities in the final translation.

- We wanted [to do this] for [April's] Fool's Day (laughs), but haven't done, and it is very funny, [....], so to find a text [... ] and then we will copy it into Google Translate and [...] (S3, age 12) - because the teacher always told us not to use Google Translate as it is not always accurate, and all kinds of stupid things would show up [be translated] (S2, age 12)

Thirdly, communication with the help of chat programmes is mentioned by a few interviewees, mainly having a private chat group which involves everyone in the German class, and students can even make comments there during the lesson. Moreover, skyping with native speakers (e.g. a friend) with whole class involvement is found to be a good idea.

To sum up, according to the teenagers who were interviewed, the use of digital devices in FL lessons promote skills development (especially productive and receptive oral skills, translation and transcription, and IT skills), group dynamic (cooperation and competition), creativity, and it also allows for opportunities for individual progress. Moreover, the cultural aspect of language learning is highlighted (skyping) as well as the benefit (faster progress) in the process of language learning with the help of new technologies. Furthermore, they think that working online supports the view of environmental consciousness (by eliminating the need for printing). In contrast with the benefits of using digital devices in institutional circumstances, some of the respondents expressed their negative opinion on this issue, e.g. that the smartphones in the language lesson may distract students' attention from the task:

Well, it depends, because there are probably a couple of people who, if they have a digital device and have their own in front of them, may not be paying attention to the task, ... (S2, age 12)

Similarly, using digital devices in FL language lessons can lead to the problem of misbehaviour. Furthermore, the problem of differentiation in regards to particular activities (e.g. watching series or films) is also pointed out, meaning that these do not meet everyone's needs, as because of the different levels of students' FL proficiency, it would work for someone, but would not work for others.

To sum up, both in the interviews and the questionnaires, similar ideas have come up. These can be grouped according to traditional and non-traditional classroom activities. It 
seems that in both cases students are open to the use of digital devices and would be pleased if they could be engaged with them in FL lessons as well.

\section{Conclusion}

The limitation of the present small-scale study is that it is not representative, but aims to explore more details to contribute to a previous study (Boldizsár, 2018) and planning further research. Furthermore, acknowledging the limitations of the study that it was done before the pandemic when online education had not come into force, the findings still suggest that teenagers are aware that using new technologies in instructional and non-instructional circumstances gives them the chance not only to improve their digital competence but also their FL proficiency. The first finding shows that interviewees mostly regarded themselves as competent users of new media technologies; they have access to a variety of digital devices, which they use every day with huge individual differences in usage time. It seems that teenagers are motivated using the new media technologies in non-educational settings mainly for watching videos, films; listening to music; visiting social media sites; using different applications for study purposes and having fun. Furthermore, the majority of interviewees realized that dealing with FL contents positively influenced their oral language skills development (speaking and listening) and vocabulary expansion.

Regarding the instructional use of digital devices, the second finding showed that the use of new media technologies was rarely experienced in the FL lessons (c.f. MOD, 2016). CD and mp3 players still seem to be the most popular technological tools in upper-primary education, which are incorporated into the language learning process relatively frequently and are mainly used for skills development. As respondents were conscious about the effectiveness of new media technologies in their FL advancement, they clearly expressed their demands towards the needs of using digital devices more frequently in the formal learning environment. The third finding of the study is that student opinion mostly reflects a rather traditional view on what these devices could be used for (e.g. skills development). However, some of them expressed their wish to do such activities that would bring them closer to real-life situations (e.g. watching, editing or creating films and videos; chatting; using various apps) with the help of smart boards, laptops, tablets and smartphones, which they are often engaged in their free time.

Hungary is a small, relatively mono-cultural and monolingual country compared to most other European countries (Vidra \& Fox, 2012). Regarding FL teaching in many educational institutions, there are some old-fashioned rules, e.g. some digital devices are not allowed to be used by students in the class (Ollé in B. Tier, 2012). FL teachers should be aware that using digital tools in the teaching-learning process comes with more advantages than disadvantages (Bucur \& Popa, 2017). As ICT is seen as a "major tool for building knowledge societies" (UNESCO 2003:1), it should be taken seriously and therefore, the educational systems and processes should be rethought and redesigned.

Since online education is taking global proportions, many other considerations have to be taken into account while discussing either the advantages of ICT or the changed roles and responsibilities of educators and foreign language teachers in this new context. The present study had been conducted before global online education started in the wake of 
the COVID-19 pandemic, so these issues do not belong to its focus. However, in regards to cultural sustainability, further studies should be conducted to explore how online education has transformed teenagers' use of new media technologies, their social interaction and their (native and non-native) language use during the pandemic. It should also be explored to what extent online communication has affected their native language proficiency (e.g. in respect to sending short messages, using incomplete sentences, nonnative abbreviations, or ignoring punctuation). As the topic of language maintenance was also brought up in this study in the context of using non-native terminologies when the Hungarian equivalent is unknown (e.g. in science, technology), as some specific vocabularies are available in the mother tongue. It might create an odd situation when they start incorporating foreign language terminologies into their native conversations. This issue belongs to the theme of cultural sustainability from the point of view of language maintenance, but there are other worth-exploring topics in sustainability, such as mass culture dominance on teenagers' identity formation or game addiction as a phenomenon.

\section{References}

Attewell, Jill (2007). BYOD for Schools: Technical advice for school leaders and IT administrators. European Schoolnet. Brussels, Belgium. [pdf] Available at: http://www.eun.org/documents/411753/817341/BYOD Technical guide full v7.pdf/ [Acc essed 16.08.2019]

Blake, Robert (2008). Brave New Digital Classroom: Technology and Foreign Language Learning. Washington, D.C.: Georgetown UP.

Boldizsár, Boglárka (2017). ICT Competence of Hungarian Foreign Language Teachers. International Journal of Arts and Sciences, 11(1), 195-202.

Boldizsár, Boglárka (2018). Students' Needs for Digital Devices in FL Classes. International Journal of Arts and Sciences, 10(1), 517-524.

B. Tier, N. (2012). Digitális készségek szerepe a tanulásban - IKT eszközök és az Internet. Interjú Ollé Jánossal. In: N. B. Tier, ed., Alma a fán - Fókusz̧ban a tanulás támogatása. Budapest: Tempus Közalapítvány, pp. 46-55. [pdf] Available at: http://www.tka.hu/docs/palyazatok/alma a fan fokuszban a tanulas tamogatasa 2014.pdf [Accessed 14 Febr. 2018].

Bucur, Norica-Felicia \& Popa, Oana-Rica (2017). Digital Competence in Learning English as a Foreign Language-Opportunities and Obstacles. The 12th International Conference on Virtual Learning ICVL 2017. 257-263. [pdf] Available at: https://www.researchgate.net/publication/320558176 Digital Competence in Learning Eng lish as a Foreign Language-Opportunities and Obstacles

Buda, András (2013). Pedagógusok az információs társadalomban. In: Lévai, Dóra \& Szekszárdi, Júlia (eds.) (2013). Digitális Pedagógus Konferencia. Konferenciakötet. ISBN 978-963-284-338-4. [pdf] Available at: http://levaid.web.elte.hu/Digitalis\%20pedagogus\%20konferencia\%202013\%20$\%$ 20Levai\%20Dora.pdf [Accessed 18.05.2018]

Cetto, Maria (2010). Technology and Second Language Teaching. Bríjula 8(1), 119-121. [pdf] Available at: www.brujula.ucdavis/edu/files/2012/01/119-21 Vol8 EnRoute Cetto.pdf [Accessed 18.05.2018]

Çöteli, Sami (2019). The Impact of New Media on The Forms of Culture: Digital Identity and Digital Culture. Online Journal of Communication and Media Technologies. 9. 1-12. 10.29333/ojcmt/5765. [pdf] Available at:

https://www.researchgate.net/publication/332950540 The Impact of New Media on The Fo rms of Culture Digital Identity and Digital Culture [Accessed 17.08.2020]

Czékmán, B., Szabó, F., Somfalvi, Z. \& Maior, E. (2017). Az IKT-val támogatott problémaalapú tanulás lehetőségei az idegennyelv-tanításban. In Polonyi T. \& Abari K. (eds.) Digitális tanulás és tanitás. pp. 69-82. Debrecen: Debreceni Egyetemi Kiadó. 
Dancsó, Tünde (2008). Az informatikai készségek vizsgálata néhány háttértényezõ tükrében. In: Csíkos Csaba, ed. VI. Pedagógiai Értékelési Konferencia. Program. Tartalmi összefoglalók. Szegedi Tudományegyetem, Szeged. 25.

Dörnyei, Zoltán (2007). Research methods in applied linguistics. New York: Oxford University Press.

Dudeney, Gavin and Hockly, Nicky (2012). ICT in ELT: How did we get here and where are we going? ELT Journal, 66(4), 533-542. https://doi.org/10.1093/elt/ccs050

Fernández-Cruz, F. J. \& Fernández-Díaz, M. J. (2016). Generation Z's Teachers and their Digital Skills. Comunicar 24(46) 97-105.

Főző, Attilia László (2006). Szinkrón és aszinkrón kommunikáció IKT alapú oktatási projektekben. Új Pedagógiai Szemle, 2006/1. 104-112.

Gfk Hungária (2010). Közel öt órát töltenek el naponta a fiatalok a számítógép és a televízió előtt. Gfk Group. [online]

Available at: http://www.gfk.com/imperia/md/content/gfk hungaria/pdf/press h/2010/press 201010 26 h.pdf [Accessed 05 March 2018].

Hanczár Gergely (2006). 17 éves tanulók informatikai kompetenciája. Doktori (PhD) értekezés. ELTE Neveléstudományi Doktori Iskola, Budapest.

Hoopingarner, Dennie (2009). Best Practices in Technology and Language Teaching. Language and Linguistics Compass 3.1(2009) 222-235.

ITTK (2007). Magyar Információs Társadalom Éves Jelentés 2006. ITTK, Budapest.

IVSZ (2017). Ajánlások a digitális pedagógia szakmai és technológiai feltételrendszeréhez. Digitális Mintaiskola Projekt. [pdf] Available at: $\underline{\mathrm{https}: / / \mathrm{dpmk} . \mathrm{hu} / \mathrm{wp}-}$ content/uploads/2018/01/Aj\%C3\%A1nl\%C3\%A1 sok-a-digit $\%$ C3\%A1lis-pedag $\%$ C3\%B3giafelt $\% \mathrm{C} 3 \% \mathrm{~A} 9$ telrendszer $\% \mathrm{C} 3 \% \mathrm{~A} 9 \mathrm{hez}$.pdf [Accessed 18.06.2019]

Jenkins, H., Clinton, K., Purushotma, R., Robinson, A. J. and Weigel, M. (2006). Confronting the Challenges of Participatory Culture: Media Education for the 21st Century. An occasional paper on digital media and learning. [pdf] Chicago: The MacArthur Foundation. Available at: https://www.macfound.org/media/article pdfs/JENKINS WHITE PAPER.PDF [Accessed 04 Jan. 2018]

Kárpáti, A. (2003). Zelig a katedrán. Az e-learning szerepe a pedagógusképzésben. Educatio, 2003/3, 389-401.

Kétyi, András (2016). Egy mobil nyelvtanulási applikáció használata és tapasztalatai a nyelvoktatásban. In: Módszertani kisérletek. Budapesti Gazdasági Egyetem, pp. 63-710.

Kétyi András (2017) A digitális hype-on túl: a 21. századi tanár digitális eszköztára. Prosperitas, 4 (4). 57-80. ISSN 2064-759X

Kuti, Zsuzsa \& Öveges, Enikő (eds.) (2016). Mi a baj ą iskolai nyelvoktatással? A Nyelvtudásért Egyesület 2016. március 5-i konferenciájának összefoglalója. [pdf] Available at: http://nyelvtudasert.hu/cms/data/uploads/konferencia-20160305-

tanulmanykotet.pdf [Accessed 24 May 2018].

Livingstone, Sonia (2003). The Changing Nature and Uses of Media Literacy. 4th ed. In: Gill, Rosalind; Pratt, Andy; Rantanen, Terhi and Couldry, Nick (eds.) MEDIA@LSE Electronic Working Papers. London: London School of Economics and Political Science. [pdf] Available at: http://www.lse.ac.uk/collections/media@lse/mediaWorkingPapers/ewpNumber4.htm

[Accessed 15 Dec. 2017].

Livingstone, Sonia (2012) Critical reflections on the benefits of ICT in education, Oxford Review of Education, 38(1), 9-24, DOI: 10.1080/03054985.2011.577938 [pdf] Available at: https://www.researchgate.net/publication/232939736 Critical Reflections on the Benefits of ICT in Education/link/588caf52a6fdcc8e63c97d8e/download [Accessed 19 May 2019].

Mátyásné Nagy, Éva (2015). Oktatástechnológia fejlesztése a köznevelésben. Opus et Educatio, 2(3), pp. 109122. [pdf]

Available at: http://epa.oszk.hu/02700/02724/00004/pdf/EPA02724 opus et educatio 201503 109122.pdf DOI: http://dx.doi.org/10.3311/ope.59 [Accessed 23 May 2018].

M. Fazekas, Ágnes and Cs. Czahesz, Erzsébet (2011). Középiskolás tanulók számítógép- és internethasználati szokásai. Iskolakultúra, 2011/8-9. pp. 120-134.

MOD. Magyarország Oktatási stratégiája. (2016). [pdf] Available at: http://www.kormany.hu/download/0/cc/d0000/MDO.pdf [Accessed 18 Oct 2018] 
Molnár, Gyöngyvér (2011). Az információs-kommunikációs technológiák hatása a tanulásra és oktatásra. Magyar Tudomány, 172(9) 1038-47. $\quad$ [pdf] Available at: http://epa.oszk.hu/00600/00691/00093/pdf/mtud 201109 1038-1047.pdf [Accessed 17 Aug 2018].

Molnár, Gyöngyvér \& Pásztor-Kovács, Anita (2015). A számítógépes vizsgáztatás infrastrukturális kérdései: az iskolák eszközparkjának helyzete és a változás tendenciái. Iskolakultúra 25 (4) 49-61.

Palys, Ted, \& Atchison, Chris (2014). Research decisions: Quantitative, qualitative, and mixed methods approaches (5th ed.). Toronto, Canada: Nelson Education.

Patton, Michael Qiunn (1999). Enhancing the quality and credibility of qualitative analysis. Health Services Research 34(5)1189-208.

Polónyi, István (2017). A válasz: az IKT az iskolában - de mi volt a kérdés? Educatio 26(2): 257-271. DOI: 10.1556/2063.26.2017.2.8.

Prensky, Marc (2001). Digital Natives, Digital Immigrants. On the Horizon MCB University Press, 9 (5) 1-6.

Ravi, B. K. (2012). New Media, Culture and Society. Academic Research International 2012/2(2) 479-494. 2012ISSN-L: 2223-9553, ISSN: 2223-9944 https://core.ac.uk/download/pdf/72802219.pdf

Rieger, Borbála (2009). Hungarian University Students' Beliefs about Language Learning: a Questionnaire Study. WoPaLP (3). 97-113.

R. Tóth, Krisztina \& Molnár, Gyöngyvér (2009). A jövõ tanárainak IKT ismeretei és elvárásai. Pedagógusképzés, 7(1) 25-41.

Sikné Lányi, Cecília (2000). 12-14 éves tanulók számítógép-használata. Magyar Pedagógia, 100 (3) 331-342.

Sós, Mária (2005). 10-14 éves diákok számítógép-használati szokásainak vizsgálata. Új Pedagógiai Szemle, 55 (11) 83-99.

Szabó, Erzsébet Mária (2012). A Laterna Magicától az okostelefonig. Az online nyelvtanulás és nyelvtanítás egy lehetséges modellje. pp. (Chapter 5). Benedek, András; Horváth Cz., János; Molnár, György; Nagy, Gábor Zsolt; Nyíri, Kristóf; Szabó Erzsébet Mária; Tóth, Péter; Verebics, János (eds). Digitális pedagógia 2.0. Available at: https://www.tankonyvtar.hu/hu/tartalom/tamop412A/2011$0023 \mathrm{DP} / \mathrm{dp} 5 \mathrm{~s}$ latmag ch000000.html

Szebeni, Rita (2010). A kompetencia alapú oktatás pedagógus személyiség háttere. Debreceni Egyetem BTK, Debrecen.

Török, Balázs (2001) A diákok számítógép-használati szokásai - internetezés és elektronikus levelezés. Új Pedagógiai Szemle, 51(7-8.) 105-122.

Treapăt, Laurențiu-Mihai (2017). The Influence of Mass-Media upon Students' Education, A Two-Edged Sword. European Journal of Business and Social Sciences. 6. 1-18.

Turcsányi-Szabó, Márta \& Abonyi-Tóth, Andor (2015). A digitális irástudás fejlesztésének lehetöségei. Budapest: Educatio Társadalmi Szolgáltató Nonprofit Kft. [pdf] Available at: http://dlsulinet.educatio.hu/download/letoltheto-dokumentumok/Digitalis-irastudas.pdf

UNESCO (2003). Communiqué. Ministerial Round Table on "Towards Knowledge Societies". Paris: UNESCO. [pdf] Available at: http://www.unesco.org/new/fileadmin/MULTIMEDIA/HQ/CI/CI/pdf/wsis geneva prep a ministerial round table communique.pdf [Accessed 23 May 2018].

Valkenburg, Patti M., \& Piotrowski, Jessica Taylor (2017). Plugged in: How media attract and affect youth. New Haven, CT; London: Yale University Press.

Vidra, Zsuzsanna, \& Fox, Jon (2012). The Radicalization of Media Discourse. The Rise of the Extreme Right in Hungary and the Roma Question. CEU CPS. 


\section{Appendix 1}

\section{Table 1. The interview questions}

General information (gender, form, length and level of foreign language studies)

Interview questions

1. What digital devices are available at home?

2. How much time do you approximately spend with these devices on weekdays or at the weekend?

3. What do you use each device for? Specify the activities!

4. Can you describe your Internet usage habits?

5. While using the Internet what language contents do you search for or websites do you visit regularly?

6. What software programs, games, online or offline applications do you most frequently use?

7. Do you think that dealing with foreign language content has contributed to the development of your oral and written language skills? If yes, in case of which domain do you feel the greatest development?

8. What digital competence do you think you have?

9. What technological tools does your foreign language teacher use in FL classes regularly or rarely? Do you find them enjoyable or useful?

10. In your opinion, what digital devices should be used to make language lessons even more motivating and useful in regards to gaining FL proficiency?

11. What do you think, for what activities could the available technological tools be used in the language lessons? Give examples and explain your ideas in detail! You can be creative! 